\title{
KAJIAN KEGUNAAN GOOGLE CLASSROOM DALAM MENINGKATKAN KEMAMPUAN BERPIKIR KRITIS PESERTA DIDIK
}

\author{
Jeni Danurahman ${ }^{1 *}$, Dikdik Baehaqi Arif ${ }^{2}$ \\ ${ }^{1}$ Pendidikan Pancasila dan Kewarganegaraan, Fakultas IImu Sosial, Universitas Negeri Yogyakarta \\ ${ }^{2}$ Pendidikan Pancasila dan Kewarganegaraan, Fakultas Keguruan dan IImu Pendidikan, Universitas \\ Ahmad Dahlan
}

\section{Edcomtech}

\section{Jurnal Kajian Teknologi Pendidikan}

Volume 6, No 2, Oktober 2021

254-263

DOI: 10.17977/um039v6i12021p254

Submitted 20-12-2020

Accepted 07-04-2021

\section{Corresponding Author*}

Jeni Danurahman

Universitas Negeri Yogyakarta

Jl. Colombo Yogyakarta No.1, Karang Malang, Caturtunggal, Kec. Depok, Kabupaten Sleman, Daerah Istimewa Yogyakarta Email:

Jenidanurahman@gmail.com

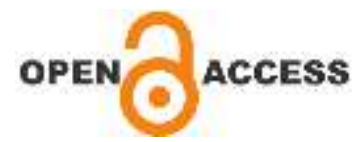

\begin{abstract}
Abstrak
Pendidikan merupakan suatu upaya untuk mencerdaskan kehidupan bangsa dan membentuk manusia yang mampu bersaing di era revolusi industri 4.0. Pesatnya teknologi informasi dan komunikasi telah berkontribusi pada sektor pendidikan. Tujuan dalam penelitian yaitu mengungkap kemampuan yang harus dimiliki abad ke 21 yaitu kemampuan berpikir kritis dan kemahiran mengoperasikan teknologi. Penelitian ini menggunakan metode analisis isi deskriptif dengan jenis analisis konten yang dirancang untuk mendeskripsikan konten informasi atau teks tertentu dengan melakukan analisis terhadap berbagai artikel ilmiah nasional, internasional maupun sumber lainnya terkait penggunaan Google Classroom selama pandemi COVID-19 dalam meningkatkan kemampuan berpikir kritis peserta didik. Dengan hasil temuan bahwa penggunaan google classroom dapat meningkatkan kemampuan berpikir kritis peserta didik.

Kata Kunci: Google Classroom, Pandemi Coronavirus Disease, Kemampuan Berpikir Kritis
\end{abstract}

\begin{abstract}
Education is an effort to educate the nation's life and form humans who can compete in the era of the industrial revolution 4.0. The rapid development of information and communication technology has contributed to the education sector. The purpose of this research is to reveal the abilities that must be possessed by the 21st century, namely the ability to think critically and the ability to operate technology. This study uses a descriptive content analysis method with a type of content analysis designed to describe certain information or text content by analyzing various national, international, and other sources of scientific articles related to the use of Google Classroom during the COVID-19 pandemic in improving students' critical thinking skills. With the findings that the use of google classroom can improve students' critical thinking skills.

Keywords: Google Classroom, Pandemic Coronavirus Disease, Critical Thinking Ability
\end{abstract}

\section{PENDAHULUAN}

Pendidikan memegang peranan penting dalam mendidik generasi penerus. Melalui pendidikan, suatu negara akan memiliki ciri khas dan daya saing yang kuat dengan negara lain. Pendidikan juga akan membangun masa depan negara dalam tindakan. Pendidikan juga merupakan faktor penting dalam upaya mempersiapkan 
sumber daya manusia yang handal, cerdas, cendekiawan, berakhlak mulia dan lain sebagainya, sedangkan pendidik memiliki tugas untuk membentuk manusia-manusia yang mampu menghadapi persaingan revolusi industri 4.0. Untuk mendukung dan mempersiapkan bangsa Indonesia menghadapi Revolusi Industri 4.0 pemerintah telah berupaya seperti halnya di bidang pendidikan telah memuat aturan mengenai penyelenggaraan sistem pendidikan di Indonesia. Sebagaimana hal tersebut tersirat dalam Undang-Undang Nomor 20 Tahun 2003.

Pasal 1 (ayat 1) Bab 1 Undang-Undang Nomor 20 tentang Sistem Pendidikan Nasional Tahun 2003 menjelaskan bahwa pendidikan adalah upaya sadar dan terencana yang bertujuan untuk menciptakan suasana belajar dan proses pembelajaran agar peserta didik dapat secara aktif mengembangkan diri. Potensi untuk menggunakan kekuatan spiritual agama dan pengendalian diri. Kepribadian, kebijaksanaan. Akhlak mulia dan keterampilan yang dibutuhkan oleh dirinya, masyarakat, bangsa, agama dan negara. Adapun Pasal 1 (ayat 3) menjelaskan bahwa pendidikan nasional berpijak pada Pancasila dan Undang-Undang Dasar Negara Republik Indonesia Tahun 1945 yang berakar pada nilai-nilai agama, budaya bangsa Indonesia dan menyesuaikan dengan perubahan zaman. Dalam pasal 3 juga dijelaskan bahwa peran pendidikan nasional adalah mengembangkan kemampuan, membentuk karakter dan peradaban bangsa yang bermartabat, mencerdaskan kehidupan bangsa, serta mendidik peserta didik menjadi beriman dan bertakwa kepada Tuhan Yang Maha Esa, berakhlak mulia, sehat, cakap, kreatif, mandiri dan warga negara yang demokratis dan bertanggung jawab.

Dalam upaya menjawab tantangan pendidikan pada era dewasa ini yaitu mengembangkan keterampilan abad ke-21, termasuk keterampilan literasi dalam teknologi informasi dan komunikasi. Keterampilan tersebut melukiskan ciri khas masyarakat global saat ini Teknologi informasi dan komunikasi (TIK) memiliki potensi yang besar sebagai media pengembangan pendidikan untuk meningkatkan keterampilan tersebut dalam proses pembelajaran. Selain itu dengan perkembangan TIK yang pesat dapat dijadikan sebagai media kegiatan belajar mengajar hal tersebut dilakukan sebagai upaya mendapatkan hasil dan kualitas belajar lebih baik dan keterampilan peserta didik seperti pada ranah kemampuan berpikir kritis. Di masa pandemi covid-19 dituntut untuk senantiasa variatif dalam proses pembelajaran agar pembelajaran menjadi berkualitas, kreatif (Pujiasih, 2020).

Keterampilan berpikir kritis sangat penting, agar peserta didik dapat menganalisis dan memecahkan masalah dalam proses pembelajaran dan kehidupan masyarakat. Ditambahkan pula menurut Kalelioğlu \& Gülbahar (2014), berpikir kritis merupakan cara berpikir atau keterampilan dengan menggunakan pendekatan informasi, sistematik serta berpikir yang dipertimbangkan secara logis untuk mengambil langkah apa yang harus dilakukan jika Anda memiliki masalah. Berpikir kritis adalah bagian dari keterampilan berpikir tingkat lanjut, kemampuan tersebut muncul ketika individu mengalami masalah baru yang bersifat dilematis dan harus mengambil sebuah keputusan. Kemampuan tersebut menghasilkan sebuah penjelasan tentang pengetahuan dan pengalaman individu yang berfungsi dalam menyelesaikan suatu masalah. Foshay \& Kirkley (2003) menunjukkan bahwa pemecahan masalah melibatkan keterampilan berpikir tingkat tinggi, seperti visualisasi, asosiasi, abstraksi, manipulasi, penalaran, analisis, sintesis, dan generalisasi.

Kemampuan berpikir kritis merupakan salah satu kemampuan yang dibutuhkan pada abad ke-21, agar dapat berpikir kritis 
perlu dikembangkan dan diajarkan di sekolah maupun perguruan tinggi khususnya di sekolah atau di perguruan tinggi formal dalam upaya menyiapkan sumber daya manusia yang mampu bersaing dan beradaptasi di era 4.0. Perkembangan teknologi informasi dan komunikasi yang pesat dapat meningkatkan keberagaman sektor termasuk di bidang pendidikan, teknologi dapat menjangkau dan diakses dimanapun kapanpun, dimanapun, terutama dalam proses kegiatan belajar mengajar. Kemudian ada penyakit pandemi coronavirus (Covid-19) yang berdampak pada semua bidang kehidupan termasuk pendidikan. Kebijakan ini dilaksanakan melalui social distancing dan bekerja dari rumah serta bertujuan untuk memutus rantai penularan Covid-19 sehingga meminimalisir kasus positif Covid-19 di Indonesia (Rochman \& Pertiwi, 2020). Namun dengan kebijakan tersebut mengakibatkan hingga kini segala bentuk aktivitas dilakukan secara daring dengan bantuan teknologi termasuk kegiatan Proses belajar mengajar di sekolah telah dialihkan ke sistem online menggunakan berbagai macam platform aplikasi yang dapat menunjang terciptanya proses belajar mengajar sehingga proses pembelajaran dapat dilaksanakan sebagaimana mestinya serta tujuan pembelajaran dapat tercapai, dengan menggunakan google classroom hal tersebut dapat dilakukan karena berbagai fitur yang disediakan oleh google classroom dapat menunjang proses kegiatan mengajar untuk mencapai tujuan pembelajaran. Di masa pandemi seperti sekarang ini segala bentuk aktivitas maupun kegiatan manusia di dukung oleh pesatnya teknologi dari segi politik, hukum, ekonomi, sosial, serta pendidikan. Karena pemberlakuan social distancing dan work from home mengakibatkan keterbatasan akses untuk bertemu langsung secara tatap muka sehingga segala bentuk kegiatan dialihkan pada sistem pendidikan tak terkecuali di bidang pendidikan. Selama pandemi berlangsung kegiatan proses belajar mengajar dialihkan melalui sistem daring yang menuntut setiap peserta didik untuk belajar di rumah dengan memanfaatkan internet, aplikasi, jurnal, website, sosial media sebagai sumber belajar. Banyak aplikasi yang menyediakan fasilitas mendukung proses kegiatan mengajar, seperti Ruang Guru, Quiper, Zenius Dan Google Classroom, yang memungkinkan pengajar dan siswa terhubung satu sama lain dengan menyediakan kelas virtual sehingga pendidik dan peserta didik dapat saling berinteraksi, berdiskusi, bertukar pikiran, pendidik dapat memberikan materi atau tugas dan banyak hal lain yang dapat dilakukan sehingga proses kegiatan belajar dapat dilaksanakan kapanpun dimanapun tak terbatas oleh ruang dan waktu.

Penelitian ini menggunakan metode descriptive content analysis study. Metode ini merupakan jenis analisis konten yang dirancang untuk mendeskripsikan konten informasi atau teks tertentu (Munirah, 2015). Analisis dilakukan terhadap berbagai artikel ilmiah terkait pembelajaran online khususnya penggunaan Google Classroom selama pandemi COVID-19 dalam meningkatkan kemampuan berpikir kritis peserta didik dari tahun 2020 sampai tahun 2021 dengan ketentuan kriteria artikel membahas keefektifan penggunaan google classroom di masa pandemi. Artikel ilmiah tersebut diperoleh dari berbagai situs jurnal seperti Scopus, Google Scholar, Directory Of Open Access Journals dan lain-lain pada jurnal internasional, maupun jurnal nasional dan sumber sejenis lainnya yang kemudian disusun dan diseleksi sesuai dengan kriteria yang ditentukan khususnya membahas penggunaan google classroom, langkah selanjutnya yaitu dilakukan kategorisasi sehingga memuat informasi yang akuntabel dan valid. 


\section{PEMBAHASAN}

\section{Tinjauan Tentang Media Google Classroom}

Pesatnya perkembangan revolusi TIK dan Industri 4.0 telah mengubah banyak bidang kehidupan dan tatanan manusia. Setiap negara berlomba untuk menciptakan suatu teknologi yang dapat membantu segala aktivitas manusia. Bukan hanya negara yang berlomba tapi beberapa perusahaan teknologi terbesar di dunia berlomba untuk menciptakan suatu teknologi mutakhir dalam upaya mengefisienkan setiap kegiatan manusia termasuk dalam bidang pendidikan. Google adalah salah satu perusahaan teknologi terbesar di dunia membuat suatu aplikasi bernama google classroom dengan tujuan untuk membuat suatu wadah agar pendidik dan peserta didik dapat berkomunikasi aktif tanpa ada batasan ruang dan waktu sehingga pembelajaran dapat dilaksanakan kapanpun dimanapun. Media pembelajaran yang bagus bisa untuk menyampaikan isi informasi pendidik kepada peserta didik, agar peserta didik memiliki kemampuan dan pemahaman terhadap materi yang dikenalkan, media pembelajaran dapat dikatakan sebagai jembatan penyampaian pengetahuan untuk mencapai tujuan pembelajaran. Banyak model media pembelajaran yang dapat digunakan untuk kegiatan mengajar antara lain media visual, media audio, media cetak, dan media elearning. E-learning merupakan terobosan yang mendukung penggunaan perangkat elektronik dengan kelebihan dan kekurangan untuk mendukung kegiatan mengajar.

Kesesuaian media e-learning dengan era kini yaitu era digital yang segala bentuk aktivitas maupun kegiatan manusia didukung oleh adanya teknologi Informasi dan komunikasi serta persyaratan abad 21 dan era revolusi industri 4.0 setiap manusia memiliki kecakapan dalam membuat atau menggunakan teknologi dalam setiap aktivitas maupun kegiatannya sehingga cepat, efektif, dan efisien. Dalam upaya mempersiapkan manusia yang dapat bersaing di era digital abad ke 21 serta revolusi industri 4.0 maka setiap Perlu mendidik peserta didik untuk menguasai teknologi informasi dan komunikasi, salah satunya adalah pemanfaatan media Google Classroom. Mengajar peserta didik secara tidak langsung menguasai teknologi informasi dan komunikasi dengan menggunakan media jenis Google dalam kegiatan mengajar. Selain itu karena adanya pandemi covid 19 maka proses kegiatan belajar mengajar dialihkan melalui sistem daring yang salah satunya dapat menggunakan google classroom.

Google Classroom menyediakan kelas virtual sehingga pendidikan dengan peserta didik dapat berinteraksi tanpa harus bertatap muka langsung namun berbagai fungsi yang disediakan oleh Google Classroom dapat secara efektif menjalankan aktivitas pengajaran, seperti pendidik menyediakan materi pembelajaran, pemberian tugas, berdiskusi, berinteraksi serta pemberian penilaian. Berbagai fitur yang telah disediakan akan memudahkan pendidik maupun peserta didik dalam mengakses google classroom sehingga pendidik maupun peserta didik dapat saling terkoneksi dan saling berinteraksi tanpa terbatas ruang dan waktu yang dapat dilakukan dimanapun dan kapanpun. Pemanfaatan google classroom dapat digunakan dalam rangka mendistribusikan bahan ajar dari pendidik kepada peserta didik. Selain itu, tampilan google classroom yang menarik juga akan membuat peserta didik tidak cepat merasa bosan dalam mengikuti kegiatan belajar mengajar, maka pendidik haruslah terampil dalam membuat kelas virtual menarik. Pendidik juga dapat membagikan materi berupa paper, video, gambar, audio, ppt, dan lain sebagainya dalam rangka menciptakan suasana belajar yang sejuk dan menarik agar siswa dapat lebih cepat memahami materi yang dikenalkan dan tujuan pembelajaran akan tercapai (Marbun, 2021) 
Selain kemudahan akses yang diberikan google classroom, google classroom juga dapat diperoleh secara gratis melalui website resmi google classroom atau melalui app store atau google play. Belanja untuk pengguna gadget/smartphone. Google Classroom dapat diakses melalui komputer/laptop atau gadget / smartphone, sehingga pengguna dapat dengan mudah mengupdate atau mengakses Google Classroom kapanpun dan dimanapun. Google Classroom adalah salah satu produk unggulan Google For Education. Sebagai perusahaan terbesar di dunia, Google berkomitmen untuk memenuhi kebutuhan dunia saat ini dan kebutuhan pendidikan yang disesuaikan. Di era sekarang, kebutuhan seperti akses yang mudah, cepat dan efisien.

Menurut Sukmawati \& Nensia (2019) menjelaskan bahwa google classroom merupakan sebuah platform pembelajaran yang dapat digunakan untuk berbagai lingkup pendidikan yang dapat diakses di semua jenjang pendidikan dari jenjang sekolah dasar hingga perguruan tinggi karena penggunaan google classroom yang memang sangat mudah digunakan maka dapat diakses oleh semua kalangan serta berbagai fitur yang menarik dan lengkap menjadi daya tarik sendiri untuk menggunakan google classroom dalam proses kegiatan belajar mengajar. Sedangkan Brock (2020) mengungkapkan bahwa google classroom merupakan sebuah aplikasi yang dapat membantu pendidik secara mudah dan efisien dalam menetapkan, mengumpulkan, dan mengem-balikan atau memberikan penilaian kepada peserta didik. Jadi pendidik selain dapat memberikan materi pembelajaran tetapi pendidik juga dapat memberikan penilaian terhadap hasil kerja peserta didik.

$$
\text { Dengan menggunakan Google }
$$
Classroom, pendidik dan siswa sebaliknya, serta siswa dan siswa dapat terhubung dan berinteraksi satu sama lain tanpa dibatasi oleh ruang dan waktu. Google classroom adalah sebuah ruang kelas berbasis online yang memungkinkan penggunanya atau pesertanya untuk dapat berkomunikasi satu sama lain, melihat presentasi, berbagi materi, menampilkan video serta dapat membuat kelompok-kelompok belajar sehingga memudahkan peserta didik maupun pendidik dalam membuat kelas virtual yang tidak terbatas ruang dan waktu sehingga dapat diakses, berinteraksi dimanapun dan kapanpun (Iftakhar, 2016), perlu diketahui bahwa google classroom telah dirilis oleh google pada tahun 2014 dalam upaya mendukung gerakan pendidikan atau google apps for education. Menurut Hakim (2016), Google Classroom adalah layanan berbasis internet yang disediakan oleh Google yaitu sistem elearning. Ini dirancang untuk membantu guru membuat dan mendistribusikan tugas kepada siswa dengan cara tanpa kertas. Oleh karena itu, Google Classroom adalah aplikasi yang disediakan oleh Google Classroom untuk membuat ruang kelas di dunia maya. Aplikasi ini dapat membantu pendidik atau pendidik untuk lebih mudah berinteraksi dengan peserta didik lebih dalam dalam proses pengajaran. Menggunakan desain ruang kelas untuk Google Kelas untuk belajar sebenarnya ramah lingkungan. Hal ini dikarenakan peserta didik tidak lagi menggunakan kertas saat mengumpulkan pekerjaan rumah. Google Classroom dapat digunakan di berbagai platform (yaitu melalui komputer atau ponsel / smartphone). Dengan cara ini, pembelajaran online memungkinkan pembelajaran memperoleh pengetahuan tanpa harus menghadiri kelas secara langsung.

$$
\text { Dalam penelitian Susanti (2017) }
$$
mengenai pemanfaatan media google classroom sebagai pembelajaran yang efektif menunjukkan bahwa adanya pengaruh yang signifikan antara pembelajaran yang efektif dengan menggunakan media pembelajaran google classroom. Qomariah \& Nursobah (2019) mengemukakan bahwa dengan penggunaan google classroom dalam proses 
pembelajaran memperoleh hasil memuaskan dan peserta pembelajaran sangat menikmati berbagai fitur pada google classroom sehingga pendidik dan peserta didik dapat terus terhubung serta memudahkan peserta didik untuk menguasai materi yang disediakan sehingga tujuan pembelajaran akan tercapai.

Sejalan dengan pernyataan diatas Sujannah et al. (2020) berpendapat bahwa dengan penggunaan google classroom dalam pembelajaran online memudahkan peserta didik maupun pendidik dalam proses pembelajaran karena google classroom dapat diakses tidak hanya dapat diakses dari komputer maupun laptop tetapi google classroom juga dapat diakses melalui tablet / smartphone sehingga dapat diakses dengan mudah dimanapun dan kapanpun. Selain itu, fitur yang disediakan oleh google classroom dapat memfasilitasi pendidik dalam membuat, berbagi, menilai materi maupun tugas dalam proses pembelajaran dengan cepat dan mudah. Selain kemudahan akses dengan penggunaan google classroom dalam proses pembelajaran akan meningkatkan hasil belajar.

Syakur et al. (2020) mengemukakan bahwa penggunaan google classroom dapat meningkatkan hasil belajar serta pembelajaran akan lebih efektif karena pendidik terfasilitasi oleh kemudahan akses dari google classroom. Dengan segala kemudahan yang ada pada google classroom tentu tidak akan memberatkan pendidik maupun peserta didik dalam pelaksanaan proses pembelajaran secara online/ daring karena google classroom sudah dibekali dengan beberapa fitur yang akan memudahkan dalam proses pengoperasiannya maupun dalam proses pembuatan kelas dan lain sebagainya karena dapat diakses dengan mudah kapanpun dan dimanapun tidak terbatas ruang dan waktu sehingga pendidik maupun peserta didik dapat membuat, berbagi, memberikan tugas maupun materi sehingga hubungan pendidik dengan peserta didik akan terus terjalin.
Google sebagai perusahaan teknologi terbesar di dunia sehingga penggunanya dapat memperoleh informasi maupun akses tak terbatas ruang dan waktu dimanapun dan kapanpun telah menyediakan beberapa aplikasi yang mendukung bidang pendidikan khususnya dalam proses pembelajaran salah satunya yaitu google classroom yang sesuai dengan tuntutan revolusi industri 4.0 agar setiap aktivitas dapat dilaksanakan secara cepat, efisien dan memperoleh hasil yang memuaskan.

Di era digital serta adanya pengaruh globalisasi setiap peserta didik maupun warga negara dituntut untuk dapat serta mampu mengoperasikan teknologi dengan pemberlakuan proses pembelajaran secara online dengan memanfaatkan platform google classroom secara tidak langsung melatih peserta didik maupun pendidik agar cakap dalam menggunakan teknologi. Beberapa faktor pendukung proses pembelajaran melalui google classroom. Menurut Hapsari \& Pamungkas (2019) yaitu faktor kesiapan pendidik yang mampu memberikan instruksi pembelajaran elearning dengan baik agar peserta didik dapat memahami apa yang disampaikan oleh pendidik, kemudian kreativitas pendidik untuk dapat memfasilitasi serta membuat materi yang menarik, agar siswa dapat aktif menjalankan proses pembelajaran, untuk memperoleh hasil yang memuaskan diharapkan sangat menarik yang memuaskan sesuai dengan harapan.

2. Kemampuan Berpikir Kritis

Berpikir kritis merupakan komponen dari kemampuan berpikir tingkat tinggi, mengacu pada kemampuan berpikir tingkat tinggi sebagai modal peserta didik sebagai warga negara muda pemecahan masalah mengacu pada teori keterampilan berpikir tingkat tinggi. Tiga jenis kritik ditetapkan. Berpikir kritis termasuk berpikir kritis sebagai kemampuan memecahkan masalah, jadi berpikir kritis adalah evaluasi dan evaluasi. Selain itu, berpikir kritis merupakan kombinasi dari penilaian dan pemecahan 
masalah. Berpikir kritis juga mengevaluasi proses berpikir dan bernalar yang mengarah pada keputusan (Halpern, 2013). Selain membantu mengevaluasi proses berpikir yang menggunakan akal dan nalar untuk mengambil keputusan. Garrett (2014) juga mengemukakan pandangan yang sama: Berpikir kritis menuntut manusia untuk dapat menganalisis, mengevaluasi, membuat, mentransfer dan merefleksikan untuk membuat keputusan yang logis dan mampu menyelesaikan masalah dengan benar metode konseptual

Berpikir kritis adalah kebiasaan menggali pengetahuan berupa informasi, berpikir bertanggung jawab, mudah beradaptasi, cepat, penilaian adil, penilaian jujur, tidak egois, mengikuti aturan, rajin mencari informasi yang relevan, dan fokus menyelidiki sesuatu Kebiasaan hal-hal ini menunjukkan bahwa berpikir kritis merupakan tahapan menuju warga negara yang ideal, warga negara dapat terus mengembangkan kreativitas dan pemikiran kritis, serta menghasilkan wawasan yang bermanfaat, yang menjadi dasar pengetahuan rasional dan demokratis. Dari pernyataan tersebut dapat disimpulkan bahwa kemampuan berpikir kritis merupakan kemampuan yang sangat penting bagi setiap orang yang terbiasa dengan serius, aktif dan cermat menganalisis semua informasi yang diterima siswa (termasuk alasan rasional) dan melakukan tindakan. benar. Menurut Lai (2011), berpikir kritis adalah gabungan keterampilan menganalisis argumen, menarik kesimpulan menggunakan penalaran induktif atau deduktif, mengevaluasi atau mengevaluasi, dan membuat keputusan atau memecahkan masalah. Pengetahuan berada dalam kondisi berpikir kritis. Penelitian empiris yang dilakukan oleh Lai (2011) menunjukkan bahwa manusia mulai mengembangkan keterampilan berpikir kritis sejak usia dini.

Oleh karena itu, disarankan agar pendidik membimbing peserta didik untuk memikirkan inti permasalahan dan menempatkan peserta didik sebagai pusat dari proses pembelajaran. Selain itu, Tsui (1999) berpendapat bahwa berpikir kritis adalah kemampuan untuk membantu memecahkan masalah akademik dan melaksanakan perubahan yang menjadikan pembelajaran lebih efektif dalam mencapai tujuan pendidikan. Dukungan tenaga pendidik yang luas memungkinkan peserta didik untuk berpikir kritis. Berpikir kritis perlu diajarkan karena berpikir kritis merupakan unsur penting dalam menguasai keterampilan berpikir tingkat tinggi dengan cara bertanya, proses introspeksi dan rekonstruksi dapat membantu siswa memperoleh kemampuan dalam memecahkan masalah dengan mengambil tindakan yang benar dan tepat (Lin \& Lee, 2013). Dari pendapat tersebut dapat diketahui, Berpikir kritis merupakan salah satu unsur kemampuan berpikir, pengetahuan, keterampilan, sikap, dan pengetahuan yang tinggi dengan berbagai pertimbangan yang dapat mereview informasi, membebaskan pikiran dan merekonstruksi pikiran, yang dapat membantu peserta didik memperoleh kemampuan dalam memecahkan masalah dan dalam kehidupan sehari-hari. Buat pilihan dalam hidup.

Sedangkan menurut Onions dalam Kalelioğlu \& Gülbahar (2014), mengungkapkan bahwa kemampuan berpikir kritis merupakan seperangkat kemampuan yang akan mendorong peserta didik memiliki pola pikir yang benar, rasional dan valid didukung dengan alasan logis yang dapat dipertanggungjawabkan. Dengan dukungan tahap teori dan kritik, pikirkan baik-baik dan tarik kesimpulan yang efektif. Sependapat dengan Elder \& Paul (1994) bahwa berpikir kritis dapat dipahami sebagai kemampuan untuk memikirkan dan mengambil keputusan. Dalam berpikir kritis, standar dan pendapat pribadi harus dikembangkan sehingga standar tersebut dapat digunakan untuk analisis dan evaluasi secara berkala untuk meningkatkan kualitas. 
Berpikir kritis adalah cara menumbuhkan keterampilan berpikir tinggi, refleksi diri, dan keterampilan pengetahuan tinggi. Saat melakukan penilaian berpikir kritis, pendidik harus menggunakan tugas terbuka untuk masalah praktis, memperhatikan latar belakang masalah, membuka pandangan tentang masalah struktural, dan meminta siswa untuk melampaui dan mengingat kembali pengetahuan yang dipelajari dari informasi sebelumnya. Selain itu, tugas penilaian harus mencakup kemampuan penalaran siswa dan memaksa siswa untuk memberikan bukti atau argumen yang mendukung penilaian, pilihan, pendapat, atau pernyataan tersebut. Oleh karena itu, dapat disimpulkan bahwa keterampilan berpikir kritis sangat penting bagi setiap orang yang terbiasa berpikir serius, berpikir aktif dan menganalisis secara cermat semua informasi yang diterima siswa (termasuk alasan rasional). Setiap tindakan itu benar. Berpikir kritis berfokus pada pemikiran, Anda dapat melihat bagaimana fakta dan bukti menyertai, pembentukan argumen dan kesimpulan.

3. Google Classroom Dapat Meningkatkan Kemampuan Berpikir Kritis

Kemampuan untuk berpikir kritis adalah salah satu komponen dari pemikiran tingkat tinggi merupakan fokus pembelajaran serta tuntutan dan kebutuhan pada abad ke-21 ini. Setiap negara berlomba termasuk Indonesia untuk mempersiapkan manusia yang mampu bersaing di masa depan. Keterampilan berpikir kritis dan kemahiran dalam penggunaan teknologi informasi merupakan indikator kemajuan suatu negara atau sistem pendidikan dijalankan oleh suatu negara dan Indonesia telah menerapkan hal itu terbukti dengan kebijakan maupun peraturan yang diterbitkan oleh pemerintah untuk mendukung pembelajaran yang mengedepankan tentang keterampilan berpikir kritis siswa dan keterampilan teknologi informasi dan komunikasi mereka.
Pesatnya perkembangan teknologi informasi dan komunikasi serta proses globalisasi telah berdampak pada semua sektor kehidupan termasuk sektor pendidikan. Teknologi kini dapat dijadikan sebagai sumber, media, dan alat dalam mendukung setiap aktivitas manusia khususnya dalam proses kegiatan belajar mengajar. Di masa pandemi kini teknologi berubah fungsi menjadi suatu kebutuhan dimana segala aktivitas manusia dapat dicapai dengan mudah dengan bantuan teknologi, seperti mencari informasi, berbelanja, melakukan transaksi, dan lain sebagainya bahkan dapat dijadikan sebagai media pembelajaran.

Google sebagai salah satu perusahaan ternama membuat suatu aplikasi dalam rangka mendukung kegiatan pendidikan yang disesuaikan dengan kebutuhan dan tuntutan di masa kini yaitu cepat, efektif, dan efisien menghadirkan google for education yang salah satu aplikasi unggulannya yaitu google classroom. Google classroom dapat dikatakan sebagai suatu aplikasi yang menyediakan kelas virtual sehingga pendidik dengan peserta didik dapat terkoneksi satu sama lain dan tidak terbatas, serta waktu dapat diakses kapanpun dan dimanapun melalui perangkat apapun (seperti laptop / gadget) setiap saat (Tarida, 2020).

Proses pendidikan abad 21 harus dapat melatih siswa yang berwawasan luas untuk memiliki kemampuan berpikir kritis yang merupakan salah satu kemampuan yang harus dimiliki setiap orang di masa depan (Solikh et al., 2018). Kemampuan berpikir kritis dan kecakapan dalam menggunakan atau mengoperasikan TIK dapat ditunjang melalui pembelajaran dengan media google classroom. Hal tersebut diperkuat oleh Rahmad et al. (2019) mengemukakan bahwa penggunaan Google Classroom dalam kegiatan pembelajaran dapat meningkatkan kemandirian dan kemampuan berpikir kritis siswa. Hasil penelitian ini sependapat dengan Zuriah 
(2020), yang menyatakan bahwa penggunaan Google Classroom dapat meningkatkan kemandirian dan kemampuan berpikir kritis siswa dalam proses pembelajaran.

Berdasarkan ungkapan tersebut membuktikan bahwa ada dampak yang signifikan dari penggunaan google classroom dijadikan sebagai media dalam proses kegiatan belajar mengajar, karena adanya menu tersebut peserta didik harus berpikir kritis agar dapat menemukan jawaban atas masalah yang dihadapinya. Tentu proses itu tidaklah mudah perlu ketelatenan dan keterampilan pendidik dalam mengorganisir, mengontrol, mengevaluasi agar pembelajaran dapat berjalan sesuai harapan untuk mencapai tujuan pembelajaran. Berdasarkan uraian di atas, maka Kurniawan (2016) menjelaskan bahwa dengan bantuan Google Classroom sebagai media pembelajaran, kemampuan berpikir kritis peserta didik akan meningkat., hal tersebut juga membuktikan bahwa ada penggunaan media Google Classroom untuk belajar berdampak besar pada peningkatan keterampilan berpikir kritis peserta didik. Selain untuk melatih peserta didik menguasai teknologi informasi dan komunikasi, media kelas google juga digunakan sebagai media pembelajaran yang merupakan kebutuhan abad ke-21 dan era digital ini, selain itu dengan menggunakan google classroom sebagai media pembelajaran dapat meningkatkan kemampuan berpikir kritis peserta didik yang merupakan salah satu kemampuan yang harus dimiliki setiap orang pada abad ke-21.

\section{PENUTUP}

Pada penelitian ini mencoba untuk mengembangkan sesuatu hal yang baru yakni penggunaan google classroom dalam proses kegiatan belajar mengajar dengan harapan dapat meningkatkan kemampuan berpikir kritis pada setiap peserta didik, mengingat di masa pandemi sekarang ini proses pembelajaran dialihkan melalui sistem daring (dalam jaringan) maka proses pembelajaran tidak terbatas ruang dan waktu dapat dilaksanakan kapanpun, dimanapun.

Hasil pada penelitian ini menunjukkan hasil bahwa dengan penggunaan google classroom dalam poses pembelajaran apabila digunakan dengan baik dan bijak akan memperoleh hasil yang baik sesuai dengan tuntutan abad ke 21 dan era revolusi industri 4.0. Pengembangan keterampilan berpikir kritis sangat penting dilakukan agar siswa dapat menganalisis dan memecahkan masalah dalam proses pembelajaran dan kehidupan masyarakat.

\section{REFERENSI}

Brock, A. (2020). Introduction to Google Classroom. Simon and Schuster.

Elder, L., \& Paul, R. (1994). Critical thinking: Why we must transform our teaching. Journal of Developmental Education, 18(1), 34.

Foshay, R., \& Kirkley, J. (2003). Principles for teaching problem solving. Technical Paper, 4(1), 1-16.

Garrett, M. L. (2014). Teaching for transfer: developing critical thinking skills with adolescent singers. The Choral Journal, 54(10), 24.

Hakim, A. B. (2016). Efektifitas Penggunaan ELearning Moodle, Google Classroom Dan Edmodo. IJTB / International Journal of Technology And Business, 2(1), 1-6.

Halpern, D. F. (2013). Thought and knowledge: An introduction to critical thinking.

Hapsari, S. A., \& Pamungkas, H. (2019). Pemanfaatan google classroom sebagai media pembelajaran online di Universitas Dian Nuswantoro. WACANA: Jurnal IImiah Ilmu Komunikasi, 18(2), 225-233. https://doi.org/https://doi.org/10.32509/ wacana.v18i2.924

Iftakhar, S. (2016). Google classroom: what works and how? Journal of Education and Social Sciences, 3(1), 12-18.

Kalelioğlu, F., \& Gülbahar, Y. (2014). The effect of instructional techniques on critical thinking and critical thinking dispositions in online discussion. Journal of Educational Technology \& Society, 17(1), 248-258. https://www.jstor.org/stable/pdf/jeductec hsoci.17.1.248.pdf

Kurniawan, H. (2016). Efektifitas pembelajaran 
problem solving dan investigasi terhadap keterampilan berpikir kritis matematis berbantuan Google Classroom. Jurnal Pendidikan Surya Edukasi, 2(1), 56-67.

Lai, E. R. (2011). Critical thinking: A literature review. In Pearson's Research Reports. images. pearsonassessments.com. http://images.pearsonassessments.com/i mages/tmrs/CriticalThinkingReviewFINAL. pdf

Lin, Y.-M., \& Lee, P.-C. (2013). The practice of business's teacher teaching: Perspective from critical thinking. International Journal of Business and Commerce, 2(6), 52-58.

Marbun, P. (2021). Disain pembelajaran online pada era dan pasca covid-19. CSRID (Computer Science Research and Its Development Journal), 12(2), 129-142. https://doi.org/http://dx.doi.org/10.22303 /csrid.12.2.2020.129-142

Munirah, F. (2015). Analisis Isi Deskriptif Rubrik “ Xp Re Si " Harian Kaltim Post Periode Maret-April 2013. EJournal IImu Komunikasi, 3(1), 186-197.

Pujiasih, E. (2020). Membangun generasi emas dengan variasi pembelajaran online di masa pandemi covid-19. Ideguru: Jurnal Karya Ilmiah Guru, 5(1), 42-48. https://doi.org/https://doi.org/10.51169/i deguru.v5i1.136

Qomariah, S., \& Nursobah, S. L. (2019). Implementasi Pemanfaatan Google Classroom untuk pembelajaran di Era Revolusi 4.0. SINDIMAS, 1(1), 227-231. https://doi.org/http://dx.doi.org/10.30700 /sm.v1i1.573

Rahmad, R., Wirda, M. A., Berutu, N., Lumbantoruan, W., \& Sintong, M. (2019). Google classroom implementation in Indonesian higher education. Journal of Physics: Conference Series, 1175(1), 12153.

Rochman, C., \& Pertiwi, C. S. R. (2020). Learning at Covid-19 pandemic era: Science technology engineering and mathematic competencies and student character. SEJ (Science Education Journal), 4(2), 129-142. https://doi.org/https://doi.org/10.21070/s ej.v4i2.574

Solikh, M. N., Sulisworo, D., \& Maruto, G. (2018). Pengaruh model pembelajaran blended learning berbantuan google classroom terhadap kemampuan berpikir kritis ditinjau dari self esteem dan kecerdasan intelektual. Jurnal Materi Dan Pembelajaran Fisika, 8(2), 27-32. https://doi.org/https://doi.org/10.20961/j mpf.v8i2.28434

Sujannah, W. D., Cahyono, B. Y., \& Astuti, U. P. (2020). Effect of Blended Learning Using Google Classroom on Writing Ability of EFL Students across Autonomy Levels. Teaching English with Technology, 20(2), 82-97.

Sukmawati, S., \& Nensia, N. (2019). The Role of Google Classroom in ELT. International Journal for Educational and Vocational Studies, 1(2), 142-145. https://doi.org/https://doi.org/10.29103/ij evs.v1i2.1526

Susanti, L. (2017). Hubungan Penggunaan Google Classroom Sebagai Pemnbelajaran Efektif Dan Paperless Terhadap Nilai Hasil Belajar Kognitif Pada Pelajaran Biologi Di SMA Charis Malang. Artikel Jurnal IT Edu Universitas Negeri Surabaya, 2(1), 1-10.

Syakur, A., Sugirin, S., \& Widiarni, W. (2020). The Effectiveness of English Learning Media through Google Classroom in Higher Education. Britain International of Linguistics Arts and Education (BIoLAE) Journal, 2(1), 475-483. https://doi.org/https://doi.org/10.33258/ biolae.v2i1.218

Tarida, L. (2020). Pemanfaatan Google Classroom dan Video Pembelajaran berbasis Problem Solving sebagai Solusi Kegiatan Belajar Mengajar di Era Pandemi Covid-19. Saintara: Jurnal IImiah IImu-IImu Maritim, 5(1), 16-20.

Tsui, L. (1999). Courses and instruction affecting critical thinking. Research in Higher Education, 40(2), 185-200. https://doi.org/https://doi.org/10.1023/A: 1018734630124

Zuriah, N. (2020). Strategy for Implementing Blended Learning With Google Classroom during the COVID-19 Pandemic Era in Higher Education. Advances in Social Science, Education and Humanities Research 477 (Iccd), 559-563. 